\begin{tabular}{c|c|c}
\hline \hline Vol. 234: 215-228, 2002 & MARINE ECOLOGY PROGRESS SERIES \\
Mar Ecol Prog Ser & Published June 3 \\
\hline
\end{tabular}

\title{
Diets of deep-sea macrourid fishes in the western Mediterranean
}

\author{
M. Carrassón*, J. Matallanas \\ Departamento de Biología Animal, Biología Vegetal y Ecología, Universidad Autónoma de Barcelona, Bellaterra, \\ 08193 Barcelona, Spain
}

\begin{abstract}
The feeding habits of the 4 most abundant macrourids that occur on the deep slope of the Catalan Sea (western Mediterranean) were examined for the first time for the Mediterranean at depths between 1000 and $2250 \mathrm{~m}$. Diets of Chalinura mediterranea, Coryphaenoides guentheri, Coelorhynchus labiatus and Trachyrhynchus trachyrhynchus were analysed for 2 seasons (summer and autumn) and/or 3 different bathymetric strata. Coryphaenoides guentheri was the most euryphagous and T. trachyrhynchus the least. Chalinura mediterranea, Coelorhynchus labiatus and T. trachyrhynchus has a benthopelagic diet, whilst Coryphaenoides guentheri has a benthic diet. Coelorhynchus labiatus has a slight preference for bathybenthic prey (polychaetes, gammaridean amphipods) whereas Chalinura mediterranea and T. trachyrhynchus display a preference for bathypelagic prey (calanoid copepods, mysids). Chalinura mediterranea and Coryphaenoides guentheri have bathymetric differences in diet marked by the capture of different prey-items and also by a greater vacuity, a greater consumption of prey and a greater diversity at 1800 to $2250 \mathrm{~m}$. A greater diversity in the diet is found in the Mediterranean populations of Chalinura mediterranea, Coryphaenoides guentheri and Coelorhynchus labiatus than in the Atlantic populations; this is probably an adaptation to the faunal paucity of the Mediterranean deep sea. General affinities among the diets of all macrourids are also analysed. The apparent coincidence between the diets of Chalinura mediterranea and T. trachyrhynchus could explain the bathymetric segregation of their respectives niches. Coelorhynchus labiatus, whose habitat width lies within those of the other 3 macrourids, has a dietary overlap intermediate to those of the other 3 macrourids. Ecological separation is maintained by a combination of differential depth distribution and feeding habits.
\end{abstract}

KEY WORDS: Chalinura mediterranea $\cdot$ Coryphaenoides guentheri $\cdot$ Macrouridae $\cdot$ Feeding ecology · Western Mediterranean · Deep-sea ecology

Resale or republication not permitted without written consent of the publisher

\section{INTRODUCTION}

The family Macrouridae is present in all oceans from subarctic to antarctic regions (Marshall \& Iwamoto 1973) and constitutes one of the most important deepwater demersal fish families. Of the approximately 300 species, $90 \%$ inhabit the continental slope areas between depths of 200 and 2000 m (Marshall 1965). Eight species of macrourids occur in the northwestern Mediterranean Sea and only 5 of them are present in the lower slope, below $1000 \mathrm{~m}$ depth. The Macrouridae are the best represented family (of the total 19 families)

*E-mail: maite.carrasson@uab.es in terms of number of species, the third in number of individuals and the fifth in terms of biomass in the Catalan deep sea between depths of 1000 and $2250 \mathrm{~m}$ (Stefanescu et al. 1992a).

Information about the distribution and biology of macrourids in the Atlantic is plentiful (e.g. McLellan 1977, Geistdoerfer 1978, 1978-1979, Mauchline \& Gordon 1984a, 1985, 1986, Gordon \& Duncan 1987, Merrett 1987, Gordon \& Mauchline 1990). In the Mediterranean, the bathymetric distribution has been studied by Macpherson (1979), Stefanescu et al. (1992a, 1994) and Massutí et al. (1995). Information on Mediterranean macrourids biology is limited. Data regarding growth, depth-size trends and morphometrics of the 
alimentary canal have been given by Morales-Nin (1990), Stefanescu et al. (1992b), Carrassón \& Matallanas (1994) and Massutí et al. (1995). Diets of macrourids for depth ranges of 200 to $800 \mathrm{~m}$ have been studied by Macpherson $(1979,1981)$, and some generic data on the diet of 1 specimen of Coryphaenoides guentheri and 1 Chalinura mediterranea from a depth of more than $2400 \mathrm{~m}$ have been reported by Geistdoerfer (1978). Apart from these 2 observations, no studies have been carried out on the diet of macrourids below a depth of $1000 \mathrm{~m}$ in the Mediterranean. In demersal deep-sea fishes in the western Mediterranean, a different behaviour in depth-size trends has been found compared to that in Atlantic waters; at the same time, a significant size reduction in Mediterranean populations of many species (among them the macrourids) has been observed compared to Atlantic populations (Stefanescu et al. 1992b). Stefanescu et al. (1993) demonstrated the existence of 2 distinct assemblages at depths between 1000 and $2250 \mathrm{~m}$ in the northwestern Mediterranean, one at 1000 to $1425 \mathrm{~m}$ and the other at 1425 to $2250 \mathrm{~m}$, where the ichthyofauna is of a largely homogeneus nature, and they also observed a transition group on the lower slope between approximately 1425 and $1800 \mathrm{~m}$. The existence of assemblages generally corresponds to important changes in the available trophic energy in the demersal ecosystem, and therefore to changes in the trophic habits of the species, such as has been observed in some species of fishes in the zone (Carrassón et al. 1997, Carrassón \& Matallanas 1998, 2001).

The object of this paper is to present and compare new and detailed information on the feeding ecology of a group of species constituting one of the main components of the deep-sea megafauna. We present a study on the trophic habits of the 4 most abundant macrourids inhabiting the lower slope (below $1000 \mathrm{~m}$ depth) of the northwestern Mediterranean: Chalinura mediterranea Giglioli, 1893, Coryphaenoides guentheri (Vaillant, 1888), Coelorhynchus labiatus (Koehler, 1896) and Trachyrhynchus trachyrhynchus (Risso, 1810). The feeding habits of Chalinura mediterranea and Coryphaenoides guentheri are analysed for different bathymetric strata, sizes of specimens and seasons. Preliminary data on the feeding habits of Coelorhynchus labiatus and T. trachyrhynchus (below $1000 \mathrm{~m}$ ) are also presented. How the factors of bathymetric strata or sizes or seasons influence the diet and patterns of dietary overlap is also discussed.

\section{MATERIALS AND METHODS}

All material was collected from the continental slope of the Catalan Sea (Western Mediterranean), during
6 cruises (BATHOS II-V, SPERMA, RETRO), on board the RV 'García del Cid' (Table 1). Samples were obtained with 2 different semi-balloon otter-trawls towed from a single warp, OTSB-14 (Merrett \& Marshall 1981) on the BATHOS and SPERMA cruises, and OTMS-27.5 (Sardà et al. 1994) on the RETRO cruise, as described in previously published papers (Stefanescu et al. 1992a, Cartes \& Sardà 1993, Stefanescu et al. 1994). The vertical opening of the trawls was $1.5 \mathrm{~m}$ and 1.8 to $2 \mathrm{~m}$ for OTSB-14 and OTMS-27.5 respectively; the horizontal opening was 7 and $14 \mathrm{~m}$ respectively. Deployment of this sort of gear is standard practice in deep-sea demersal sampling; it can be therefore assumed that results drawn from such surveys in different areas are comparable (cf. Haedrich \& Merrett 1988).

A total of 994 specimens (191 Chalinura mediterranea, 611 Coryphaenoides guentheri, 43 Coelorhynchus labiatus, 149 Trachyrhynchus trachyrhynchus) were collected between depths of 1000 and $2250 \mathrm{~m}$ to examine feeding activity (Table 1). These 4 species are found in the North Atlantic as well as in the Mediterranean (Geistdoerfer 1986). In the western Mediterranean, the bathymetric distribution of Chalinura mediterranea and Coryphaenoides guentheri is restricted to depths greater than $1300 \mathrm{~m}$, but down to 1500 to $1600 \mathrm{~m}$ they appear only occasionally (Stefanescu et al. 1992a). Coelorhynchus labiatus occurs between 1200 and $1600 \mathrm{~m}$, and its occurrence outside this range is rare (Stefanescu et al. 1992a). $T$. trachyrhynchus occurs down to $1589 \mathrm{~m}$, but its maximum abundance and biomass lie outside this depth range, between 900 and $1000 \mathrm{~m}$ (Massutí et al. 1995), and below $1300 \mathrm{~m}$ it is rare (Stefanescu et al. 1992a).

All specimens were fixed in $10 \%$ formalin immediately after capture. Once in the laboratory, they were measured (total length, TL, to the nearest millimeter) and dissected to analyse stomach contents.

Food items were identified to the lowest taxonomic level possible. Numbers and weights were recorded to the nearest $0.1 \mathrm{mg}$ after drying with blotting paper to remove surface moisture.

The quantitative importance of each prey group in the diet was determined by the index of relative importance (IRI, Pinkas et al. 1971), defined as:

$$
\text { IRI }=\% F(\% N+\% V)
$$

where $\% F=$ frequency of occurrence of a food item in the stomachs of a whole sample; $\% N=$ numerical percentage of a food item in the stomachs, and \% $V=$ percentage by volume of a food item in the stomachs (Hureau 1970). In the present study, weight ( $\% W$ ) was used instead of volume $(\% V)$. This modified index is expressed as \%IRI $=($ IRI $/$ IIRI $) \times 100($ Rosecchi \& Nouaze 1987). Prey were sorted in decreasing order of 
Table 1. Chalinura mediterranea (C. m.), Coryphaenoides guentheri (C. g.), Coelorhynchus labiatus (C. l.) and Trachyrhynchus trachyrhynchus $(T . t$.) sampling data. L(N): Latitude North; L(E): Longitude East; B: BATHOS cruises; SP: SPERMA cruise; R: RETRO cruise

\begin{tabular}{|c|c|c|c|c|c|c|c|c|}
\hline \multirow[t]{2}{*}{ Station } & \multirow{2}{*}{$\begin{array}{c}\text { Date } \\
\text { (dd/mm/yy) }\end{array}$} & \multirow{2}{*}{$\begin{array}{c}\text { Depth (m) } \\
\text { (initial-final) }\end{array}$} & \multicolumn{2}{|c|}{ Final position } & \multicolumn{4}{|c|}{ No. of specimens } \\
\hline & & & $\mathrm{L}(\mathrm{N})$ & $\mathrm{L}(\mathrm{E})$ & C. $m$. & C. $g$. & C. 1 . & T. $t$. \\
\hline BII-5 & $30 / 07 / 87$ & $1715-1753$ & $40^{\circ} 25.4^{\prime}$ & $1^{\circ} 56.9^{\prime}$ & 16 & 29 & & \\
\hline BIII-3 & $25 / 06 / 88$ & $1774-1783$ & $40^{\circ} 18.5^{\prime}$ & $1^{\circ} 57.2^{\prime}$ & 12 & 136 & & \\
\hline BIII-4 & $26 / 06 / 88$ & $2163-2039$ & $40^{\circ} 37.7^{\prime}$ & $3^{\circ} 06.2^{\prime}$ & 34 & 110 & & \\
\hline BIII-5 & $26 / 06 / 88$ & $2256-2239$ & $40^{\circ} 32.3^{\prime}$ & $3^{\circ} 44.7^{\prime}$ & 8 & & & \\
\hline BIII-6 & $27 / 06 / 88$ & $1857-1855$ & $40^{\circ} 32.9^{\prime}$ & $2^{\circ} 51.4^{\prime}$ & 1 & 26 & & \\
\hline BIII-7 & $27 / 06 / 88$ & $1539-1621$ & $40^{\circ} 09.2^{\prime}$ & $3^{\circ} 01.0^{\prime}$ & 1 & 30 & 14 & \\
\hline BIII-8 & $28 / 06 / 88$ & $1737-1729$ & $40^{\circ} 16.7^{\prime}$ & $2^{\circ} 54.8^{\prime}$ & 1 & 32 & & \\
\hline BIII-9 & $30 / 06 / 88$ & $2193-2198$ & $40^{\circ} 38.7^{\prime}$ & $3^{\circ} 23.1^{\prime}$ & & 25 & & \\
\hline BIII-11 & 02/07/88 & $1520-1429$ & $40^{\circ} 57.6^{\prime}$ & $2^{\circ} 23.3^{\prime}$ & 6 & 6 & & \\
\hline BIII-12 & 02/07/88 & $1617-1635$ & $40^{\circ} 57.3^{\prime}$ & $2^{\circ} 32.3^{\prime}$ & 8 & 28 & 1 & \\
\hline BIII-15 & 03/07/88 & $1015-996$ & $40^{\circ} 55.3^{\prime}$ & $1^{\circ} 44.4^{\prime}$ & & & & 4 \\
\hline BIII-16 & 04/07/88 & $1235-1214$ & $40^{\circ} 45.2^{\prime}$ & $1^{\circ} 38.8^{\prime}$ & & & 6 & \\
\hline BIII-17 & $04 / 07 / 88$ & $1393-1434$ & $40^{\circ} 45.8^{\prime}$ & $1^{\circ} 55.4^{\prime}$ & & 6 & & \\
\hline BIII-28 & $11 / 07 / 88$ & $1820-1927$ & $40^{\circ} 26.4^{\prime}$ & $2^{\circ} 37.7^{\prime}$ & 4 & 4 & & \\
\hline BIV-1 & $26 / 07 / 88$ & $1002-970$ & $41^{\circ} 21.5^{\prime}$ & $3^{\circ} 18.6^{\prime}$ & & & & 25 \\
\hline BIV-2 & $26 / 07 / 88$ & $2017-2083$ & $41^{\circ} 17.5^{\prime}$ & $3^{\circ} 27.4^{\prime}$ & 3 & 9 & & \\
\hline BIV-3 & $27 / 07 / 88$ & $2158-2188$ & $41^{\circ} 08.5^{\prime}$ & $3^{\circ} 32.1^{\prime}$ & 31 & 30 & & \\
\hline BIV-4 & $28 / 07 / 88$ & $2071-1880$ & $41^{\circ} 05.0^{\prime}$ & $3^{\circ} 06.7^{\prime}$ & 12 & 41 & & \\
\hline BIV-6 & $28 / 07 / 88$ & $1837-1880$ & $41^{\circ} 14.2^{\prime}$ & $3^{\circ} 17.3^{\prime}$ & 3 & 59 & & \\
\hline BIV-7 & $29 / 07 / 88$ & $2198-2221$ & $41^{\circ} 05.1^{\prime}$ & $3^{\circ} 29.4^{\prime}$ & 42 & & & \\
\hline BIV-8 & $29 / 07 / 88$ & $1784-1765$ & $41^{\circ} 07.1^{\prime}$ & $2^{\circ} 46.6^{\prime}$ & 9 & 9 & & \\
\hline BIV-9 & $30 / 07 / 88$ & $1823-1796$ & $41^{\circ} 44.0^{\prime}$ & $2^{\circ} 28.6^{\prime}$ & & 6 & & \\
\hline BIV-10 & $30 / 07 / 88$ & $1284-1286$ & $40^{\circ} 58.8^{\prime}$ & $2^{\circ} 18.6^{\prime}$ & & & 3 & 3 \\
\hline BIV-11 & $31 / 07 / 88$ & $1531-1471$ & $41^{\circ} 03.5^{\prime}$ & $2^{\circ} 37.2^{\prime}$ & & & 2 & \\
\hline BIV-12 & $31 / 07 / 88$ & $1317-1329$ & $41^{\circ} 02.6^{\prime}$ & $2^{\circ} 23.1^{\prime}$ & & & 3 & 2 \\
\hline BV-10 & $27 / 10 / 88$ & $1014-1004$ & $40^{\circ} 53.9^{\prime}$ & $1^{\circ} 45.0^{\prime}$ & & & & 19 \\
\hline BV-11 & $28 / 10 / 88$ & $1036-1026$ & $40^{\circ} 55.4^{\prime}$ & $1^{\circ} 52.6^{\prime}$ & & & & 36 \\
\hline BV-13 & $28 / 10 / 88$ & $1085-961$ & $40^{\circ} 57.4^{\prime}$ & $2^{\circ} 07.5^{\prime}$ & & & & 25 \\
\hline BV-14 & $28 / 10 / 88$ & $1158-1165$ & $41^{\circ} 00.3^{\prime}$ & $2^{\circ} 11.3^{\prime}$ & & & & 10 \\
\hline BV-16 & $29 / 10 / 88$ & $1008-1089$ & $41^{\circ} 06.9^{\prime}$ & $2^{\circ} 22.9^{\prime}$ & & & & 11 \\
\hline SP-3 & $17 / 10 / 89$ & $1772-1808$ & $40^{\circ} 20.9^{\prime}$ & $2^{\circ} 01.2^{\prime}$ & & 40 & & \\
\hline SP-5 & 18/10/89 & $1478-1547$ & $40^{\circ} 04.5^{\prime}$ & $1^{\circ} 38.4^{\prime}$ & & & 1 & \\
\hline SP-6 & 19/10/89 & $1289-1301$ & $38^{\circ} 15.4^{\prime}$ & $1^{\circ} 05.9^{\prime}$ & & & 1 & \\
\hline R1-9 & $25 / 04 / 91$ & $1267-1167$ & $41^{\circ} 93.1^{\prime}$ & $2^{\circ} 20.3^{\prime}$ & & & 12 & 14 \\
\hline
\end{tabular}

their \%IRI contribution, and the cumulative \%IRI was calculated (the sum of the IRI of 1 prey with all the preceding in the list). Prey were classified into 3 categories, according to their contribution to the cumulative \%IRI (Rosecchi \& Nouaze 1987): preferential prey (the first prey on the list whose contribution increased the accumulative \%IRI to at least $50 \%$ of the total \%IRI); secondary prey (the next prey on the list whose cumulative \%IRI, when added to that of the preferential prey, increased the accumulative IRI to approximately $75 \%$ of the total \%IRI); and accidental prey (the remaining prey).

The diet of Chalinura mediterranea was studied for 2 bathymetric strata: 1425 to $1800 \mathrm{~m}$ and 1800 to $2250 \mathrm{~m}$.

To analyse the diet of Coryphaenoides guentheri, individuals from all trawls were grouped according to capture depth (2 bathymetric strata: 1425 to $1800 \mathrm{~m}$ and 1800 to $2250 \mathrm{~m}$ ), season (summer and autumn) and size of individuals (2 categories: Size 1, total length $<173.5 \mathrm{~mm}$; Size 2, total length $\geq 173.5 \mathrm{~mm}$ ). There are no studies in the literature on the size at maturity of $C$. guentheri in the Mediterranean, so we attempted to calculate this using our specimens in order to be able to analyse possible variations in diet between the juveniles and adults. Our C. guentheri were not in their reproductive season, but small atresic eggs were found in the gonads with a weight of $>0.03 \mathrm{~g}$. From this, we calculated a possible size at maturity of $173.5 \mathrm{~mm}$, the TL which separates our 2 size classes. The \%IRI of the main prey items was determined for each of the 5 combinations (see Table 2) of depth, season and size by pooling diet data from the individuals included in each combination. The affinity of these 5 combinations was computed using hierarchical analysis (unweighted pair-group method using arithmetic averages, UPGMA, as the aggregation algorithm, with Euclidean distance as a measure of similarity). 
A food-intensity index $(K)$ was determined using the average index of the amount of food eaten per fish (weight of the stomach contents $\times 100$ /weight eviscerated fish: Yasuda 1960). Trophic diversity $\left(H^{\prime}\right)$ was calculated, in terms of mean \% weight of prey-items using the Shannon index. In Chalinura mediterranea and Coryphaenoides guentheri, degree of overlap of different bathymetric strata and seasons was determined also, based on mean \% weight results, using the quantitative Schoener index (Schoener 1974).

\section{RESULTS}

\section{Chalinura mediterranea}

Of the 191 specimens analysed, 28 had the stomach everted, and of the remaining 163, 40 were empty. From the 123 stomachs containing food, 43 categories of prey items were identified (Table 2).

The diet was dominated by Mysidacea (\%IRI = 32.70) and Copepoda ( $\%$ IRI = 26.13). Gammarid Amphipoda $(\%$ IRI $=22.87)$ were secondary prey. Polychaete and decapod Natantia were the main accidental groups.

Individuals from 1425 to $1800 \mathrm{~m}$ : The diet of 40 specimens collected indicated that copepods (mainly calanoids) and mysids were the most consumed prey groups. Copepods were abundant $(\% N=31.36)$ and

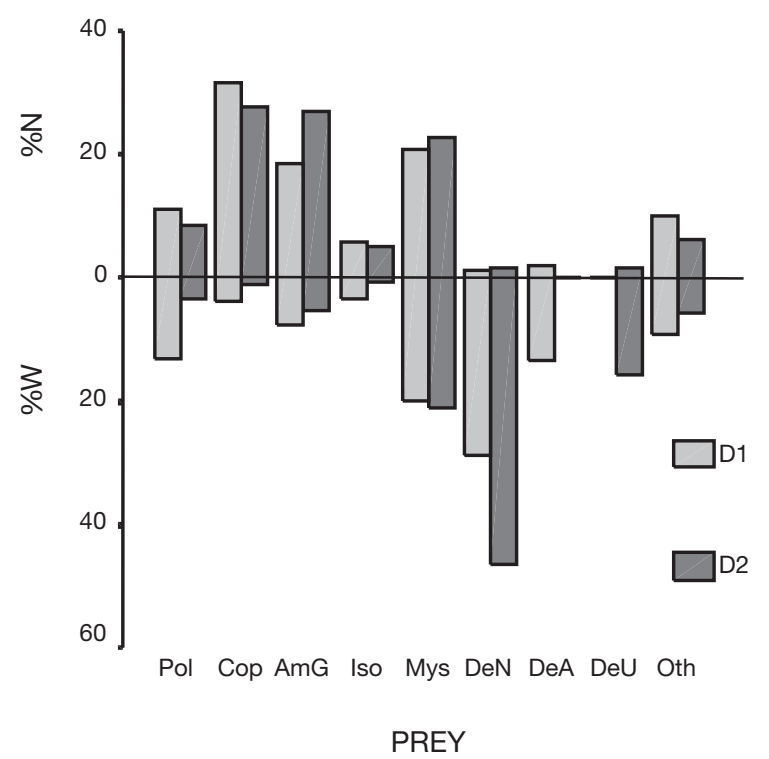

Fig. 1. Chalinura mediterranea. Percentage by number $(\% N)$ and by weight $(\% W)$ of prey species in the diet of individuals from 1425 to $1800 \mathrm{~m}$ depth (D1) and individuals from 1800 to 2250 m depth (D2). Pol: Polychaeta; Cop: Copepoda; AmG: amphipod Gammaridea; Iso: Isopoda; Mys: Mysidacea; DeN: decapod Natantia; DeA: decapod Anomura; DeU: unidentified decapod; Oth: others the importance of mysids was related to their high weight ( $\% W=20.00$ : Fig. 1). Boreomysis arctica was the mysid most frequently captured. Gammaridean amphipods and polychaetes were secondary prey $(\%$ IRI $=19.41$ and 16.30 respectively: Table 2$)$ and the rest accidental prey.

Individuals from 1800 to $2250 \mathrm{~m}$ : Of the 83 specimens analysed the mysids and copepods were the dominant prey, the gammaridean amphipods the secondary prey, and polychaetes and natantian decapods the major accidental prey. Copepods were the most abundant $(\% N=27.70)$ and natantian decapods the heaviest prey (\% $W=46.4$ ) (Fig. 1), but due to their low frequency and abundance the latter had a low \%IRI $(5.3 \%)$. Boreomysis arctica was the more abundant mysid captured and Rhachotropis sp. the most abundant amphipod in the diet.

In terms of the different depth ranges, the ratio of full foreguts at 1425 to $1800 \mathrm{~m}$ was lower than at 1800 to $2250 \mathrm{~m}$ (Table 3 ), but not significantly ( $\mathrm{p}>0.05$, $\chi^{2}$ criterion).

$K$ reached its statistically significant maximum in specimens caught between 1800 and 2250m (Table 3; Student's $t$-test, $\mathrm{p}<0.01)$. The average number of prey per stomach $\left(N_{\mathrm{p}}\right)$ and the average weight of prey per stomach $\left(W_{\mathrm{p}}\right)$ showed a similar trend to $K$ (Table 3$)$; the largest and most numerous prey were consumed at 1800 to $2250 \mathrm{~m}$, but the differences were not significant (both $t$-test, $\mathrm{p}>0.05$ ).

Trophic diversity values $\left(H^{\prime}\right.$ : Table 3$)$ were higher at the maximum depth. Dietary overlap (Schoener index) was 0.629 between groups from 1425 to $1800 \mathrm{~m}$ and 1800 to $2250 \mathrm{~m}$.

\section{Coryphaenoides guentheri}

Of the 626 specimens analysed, 132 had everted stomachs and 76 had empty stomachs. From the 418 stomachs containing food, 94 categories of prey items were identified (Table 2).

Gammarid amphipods were the preferred prey ( $\%$ IRI $=46.90)$, being the most abundant the most frequently captured, and the heaviest prey. Cumaceans were secondary prey $(\%$ IRI $=22.25)$, and polychaetes accidental ( $\%$ IRI $=14.91)$.

The cluster analysis of the size, season and depth combinations identified 3 groups (Fig. 2). The specimens collected at depths of 1425 to $1800 \mathrm{~m}$ in autumn (Group A) were clearly separated in the dendogram from all the summer individuals. Size 1 and Size 2 in all categories were clustered together, being grouped together with individuals collected at 1425 to $1800 \mathrm{~m}$ in summer (Group B), and the 1800 to $2250 \mathrm{~m}$ specimens (Group C). 


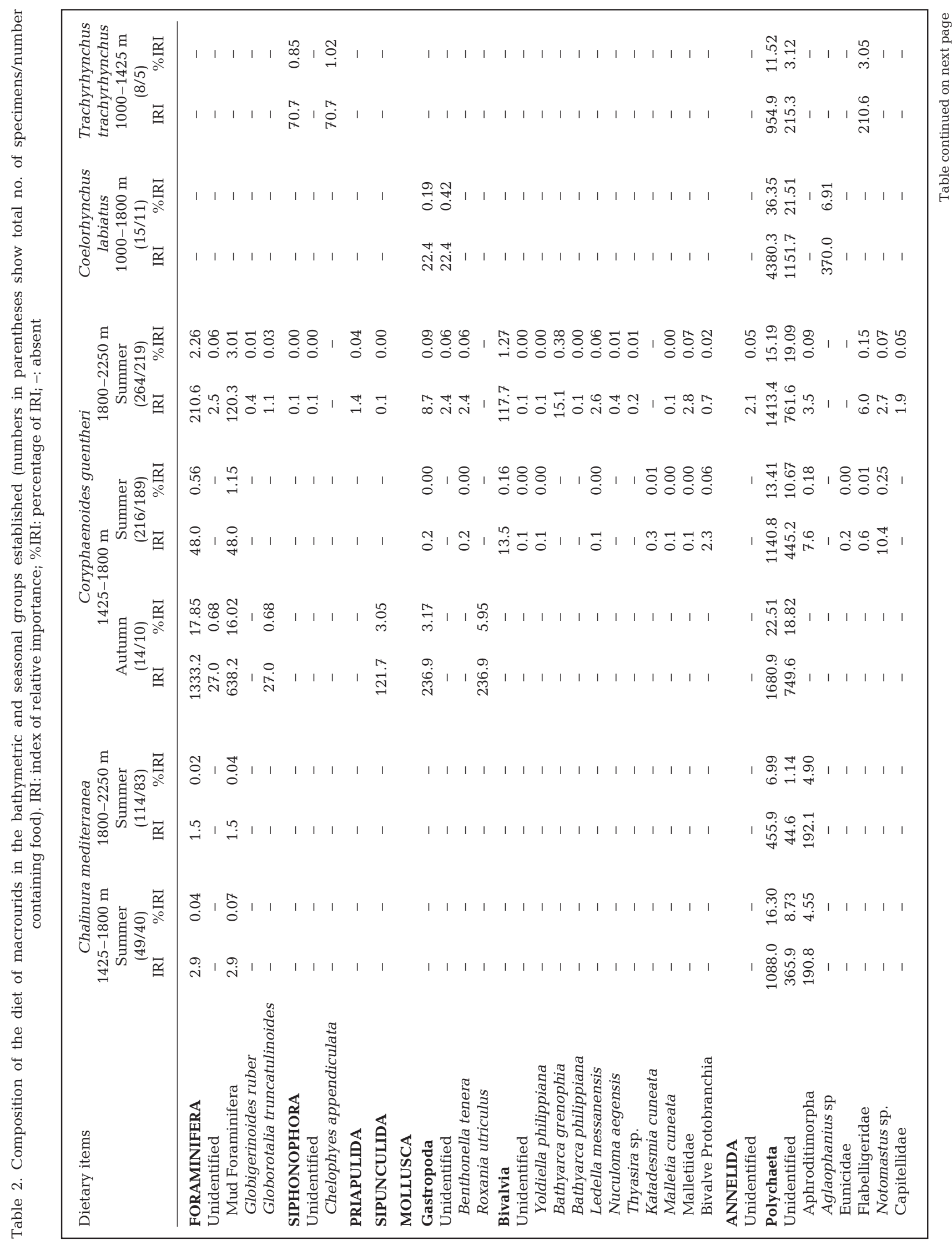




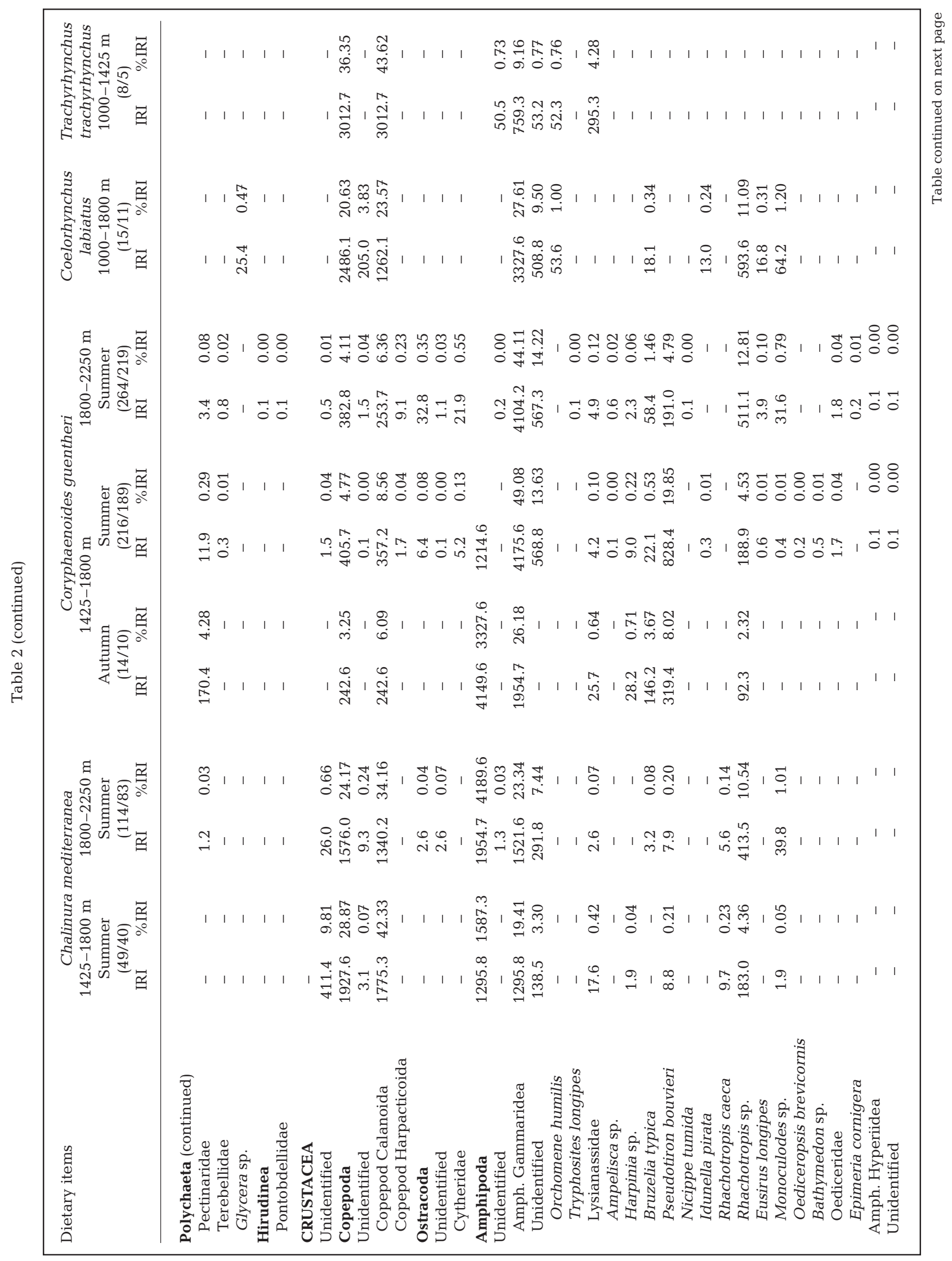




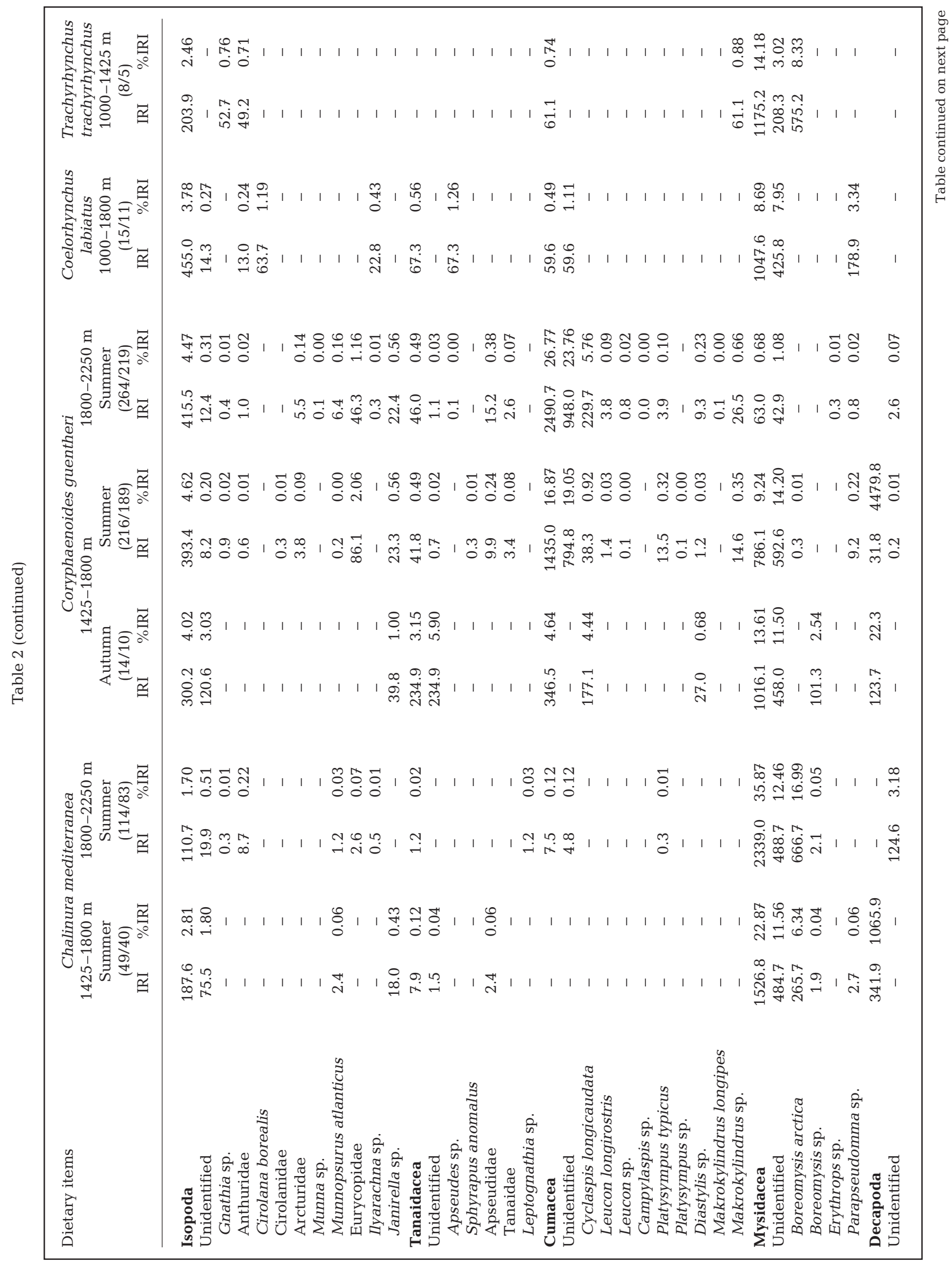




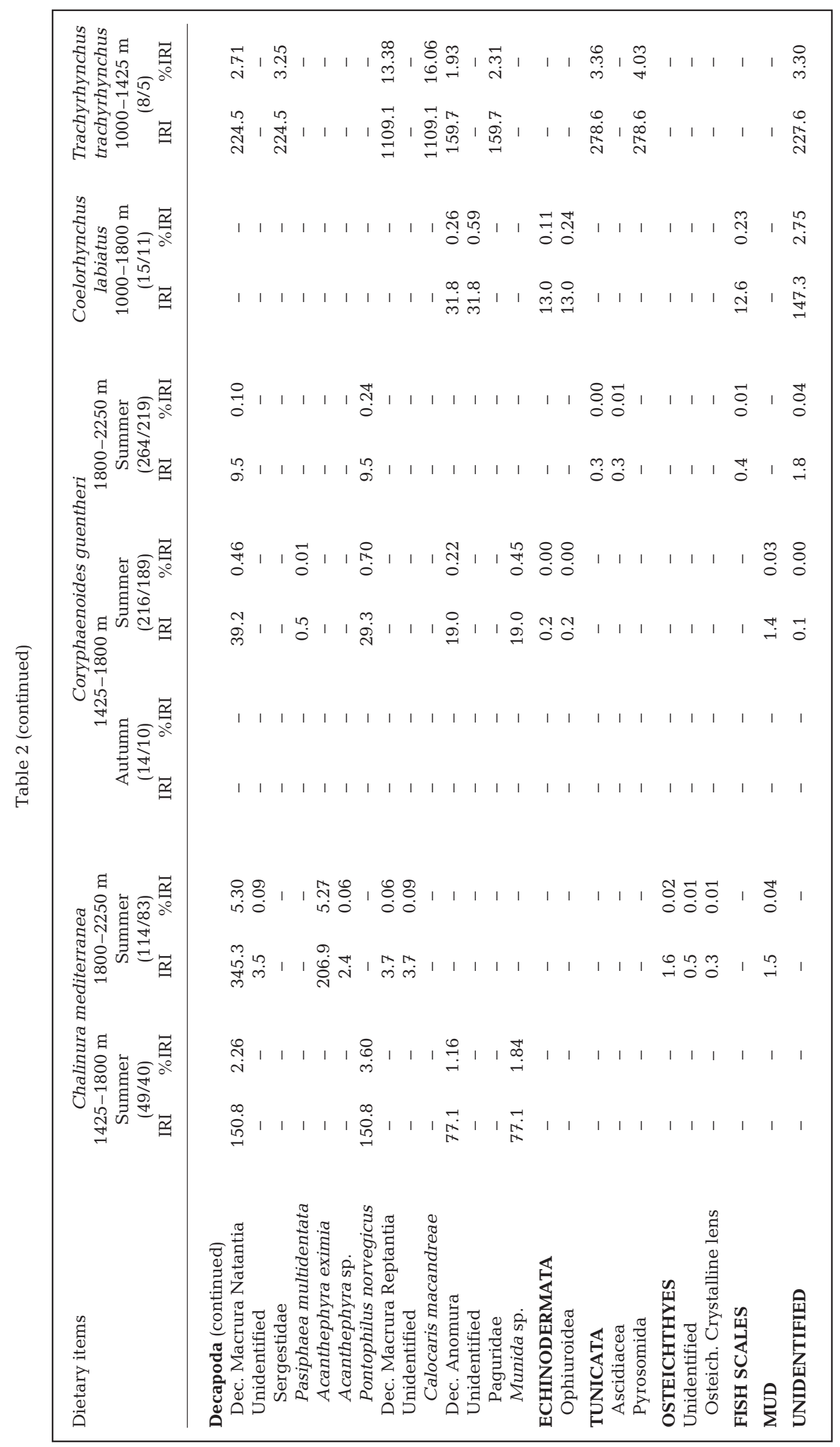


Table 3. Chalinura mediterranea, Coryphaenoides guentheri, Coelorhynchus labiatus and Trachyrhynchus trachyrhynchus. Vacuity percentage, food intensity index, trophic diversity (Shannon index), mean number of prey and mean weight of prey in each bathymetric (D1: 1425 to $1800 \mathrm{~m}, \mathrm{D} 2: 1800$ to $2250 \mathrm{~m}$ ) and seasonal group established

\begin{tabular}{|c|c|c|c|c|c|c|c|}
\hline & \multicolumn{2}{|c|}{ C. mediterranea } & \multicolumn{3}{|c|}{ - C. guentheri } & \multirow[t]{3}{*}{ C. labiatus } & \multirow{3}{*}{$\begin{array}{l}\text { T. trachy- } \\
\text { rhynchus }\end{array}$} \\
\hline & \multirow[t]{2}{*}{ D1 } & \multirow[t]{2}{*}{ D2 } & \multicolumn{2}{|c|}{ D1 } & \multirow{2}{*}{$\begin{array}{c}\text { D2 } \\
\text { Summer }\end{array}$} & & \\
\hline & & & Autumn & Summer & & & \\
\hline Vacuity percentage $(V)$ & 18.37 & 27.19 & 28.57 & 12.50 & 17.05 & 26.67 & 37.50 \\
\hline Food intensity index $(K)$ & 0.0728 & 0.2468 & 0.0806 & 0.0926 & 0.0988 & 0.1786 & 0.1491 \\
\hline Trophic diversity $\left(H^{\prime}\right)$ & 3.79 & 4.01 & 3.43 & 4.48 & 4.87 & 3.88 & 3.05 \\
\hline Mean number of prey $(N p)$ & 4.22 & 5.17 & 4.10 & 5.13 & 5.82 & 6.82 & 8.20 \\
\hline Mean weight $(g)$ of prey $(W p)$ & 0.0100 & 0.0246 & 0.0078 & 0.0069 & 0.0067 & 0.0193 & 0.0913 \\
\hline
\end{tabular}

\begin{tabular}{|c|c|c|c|c|c|c|}
\hline \multirow[b]{2}{*}{ C A S E } & \multicolumn{6}{|c|}{ Rescaled Distance among Clusters } \\
\hline & 0 & 5 & 10 & 15 & 20 & 25 \\
\hline \multicolumn{7}{|l|}{ D2Ss1 } \\
\hline \multicolumn{7}{|l|}{$\mathrm{D} 2 \mathrm{Ss} 2$} \\
\hline \multicolumn{7}{|l|}{ D1Ss1 } \\
\hline D1Ss2 & & & B & & & \\
\hline D1As1 & & & & & & \\
\hline
\end{tabular}

Fig. 2. Coryphaenoides guentheri. Dendrogram of dissimilarity between diets of different groups (bathymetric, seasonal and ontogenic). D2Ss1: immature (Size 1) summer individuals from 1800 to $2250 \mathrm{~m}$ depth; D2Ss2: mature (Size 2) summer individuals from 1800 to $2250 \mathrm{~m}$ depth. D1Ss1: immature (Size 1) summer individuals from 1425 to $1800 \mathrm{~m}$ depth; D1Ss2: mature (Size 2) summer individuals from 1425 to $1800 \mathrm{~m}$ depth; D1As1: immature (Size 1) autumn individuals from 1425 to $1800 \mathrm{~m}$ depth; groups identified: $\mathrm{A}=\mathrm{D} 1 \mathrm{As} 1$; $\mathrm{B}=\mathrm{D} 1 \mathrm{Ss} 1$ and D1Ss2, C = D2Ss1 and D2Ss2

Group A, 1425 to $1800 \mathrm{~m}$ in autumn: The high percentage of everted stomachs $(65 \%)$ and vacuity ( $V=$ $28.57 \%$ ) precludes conclusions. In 10 specimens with food, gammarid amphipods ( $\%$ IRI $=26.18$ ) and polychaetes $(\% \operatorname{IRI}=22.51)$ were the dominant prey (Table 2$)$, the polychaetes being the heaviest $(\% W=$ 32.30: Fig. 3). The importance of amphipods was due to the combination of frequency and abundance of species such as Pseudotiron bouvieri, Bruzelia typica and Rhachotropis sp. Foraminifera and mysids were secondary groups, and the rest were accidental items.

Group B, 1425 to $1800 \mathrm{~m}$ in summer: In 189 specimens analysed the most important prey-group was gammarid amphipods. Their high frequency $(\% F=$ 74.60) and abundance ( $\% N=30.30$ : Fig. 3$)$ resulted in a \%IRI of 49.08, the amphipod Pseudotiron bouvieri being the first preferred prey-item $(\%$ IRI $=19.85$ : Table 2). Cumaceans and polychaetes were secondary prey, while mysids were the major accidental prey $(\%$ IRI $=9.24)$.

Group C, 1800 to 2250 m: Similar to Group B, gammarid amphipods predominated in the 219 specimens analysed $(\%$ IRI $=44.11)$, but the primary amphipod species was Rhachotropis sp. (\%IRI = 12.81), while cumaceans were secondary $(\% \operatorname{IRI}=26.77)$. Poly-

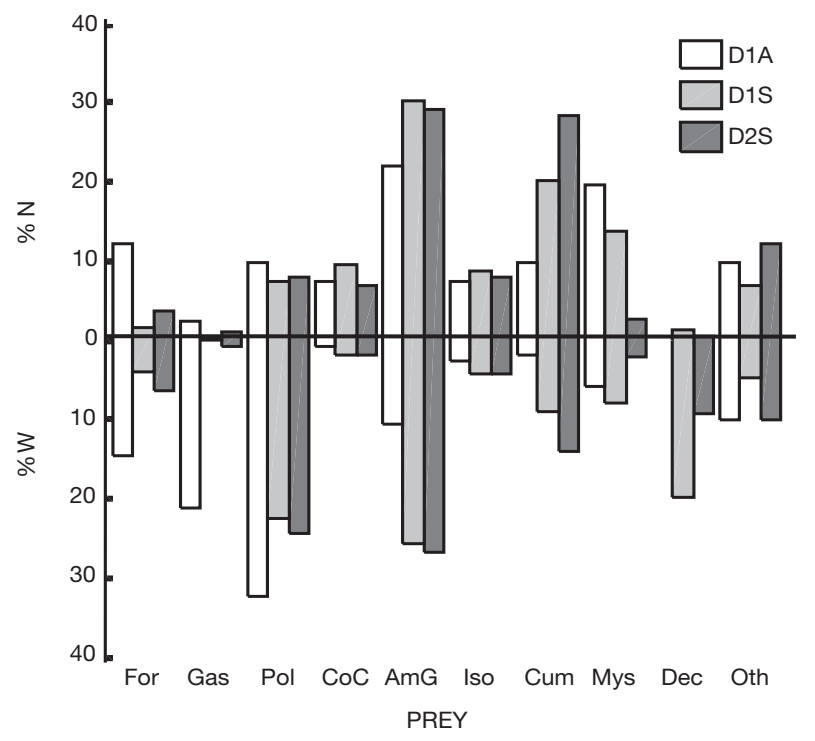

Fig. 3. Coryphaenoides guentheri. Percentage by number $(\% N)$ and by weight $(\% W)$ of prey species in the diet of autumn individuals from 1425 to $1800 \mathrm{~m}$ depth (D1A) summer individuals from 1425 to $1800 \mathrm{~m}$ depth (D1S), and summer individuals from 1800 to $2250 \mathrm{~m}$ depth (D25). For: Foraminifera; Gas: Gastropoda; Pol: Polychaeta; CoC: copepod Calanoida; AmG: amphipod Gammaridea; Iso: Isopoda; Cum: Cumacea; Mys: Mysidacea; Dec: Decapoda; Oth: others 
chaetes were the major accidental prey $(\%$ IRI $=15.19)$ because of their high weight (Fig. 3).

In terms of different seasons and depths, no significant differences were found in any of the indices analysed: vacuity coefficient ( $\mathrm{p}>0.05, \chi^{2}$ criterion), food intensity index $K$ (ANOVA, p > 0.05), average number of prey per stomach $\left(N_{\mathrm{p}}\right)$ and average weight of prey per stomach $\left(W_{\mathrm{p}}\right)$ (both ANOVA with $\mathrm{p}>0.05$ ) (Table 3).

Trophic diversity $\left(H^{\prime}\right.$ : Table 3$)$ was lowest at depths of 1425 to $1800 \mathrm{~m}$ in autumn and higher at 1800 to $2250 \mathrm{~m}$ in summer. Dietary overlap was high (overlap, Schoener index $=0.708$ ) among groups from 1425 to $1800 \mathrm{~m}$ and 1800 to $2250 \mathrm{~m}$ in summer. Affinity between the diets of summer and autumn specimens at all depths was low (Schoener autumn 1425-1800 m with summer $1425-1800 \mathrm{~m}=0.469 ;$ Schoener $_{\text {autumn } 1425-1800 \mathrm{~m} \text { with summer }}$ $1800-2250 \mathrm{~m}=0.425)$.

\section{Coelorhynchus labiatus}

Only 11 stomachs of Coelorhynchus labiatus with food were analysed, due to the high number of everted and empty stomachs (32 of 43 specimens). Polychaetes and gammarid amphipods were the dominant prey, while copepods were secondary prey. Polychaetes were the most weighted prey-group ( $\% W=59.5)$, and, in spite of their low abundance $(\% N=9.33)$, they were the primary preferred prey-group $(\%$ IRI $=36.35)$ (Table 2). Gammarid amphipods were the most abundant prey-group ( $\% N=30.67)$. The contribution of the remaining prey was accidental $(\%$ IRI < 9). C. labiatus contained a large number of prey items per stomach $\left(N_{\mathrm{p}}=6.82\right)$, with an average weight per stomach of $0.0193 \mathrm{~g}$ (Table 3).

\section{Trachyrhynchus trachyrhynchus}

The diet of Trachyrhynchus trachyrhynchus at depths between 1000 and $1425 \mathrm{~m}$ in the Mediterranean are analysed here for the first time. The high number of everted stomachs, caused by the expansion of the swimbladder during ascent to the surface (141 of the 149 specimens analysed) hinders conclusions regarding the food and feeding habits of this species on the middle slope (under $1000 \mathrm{~m}$ depth). Of the 8 stomachs not everted and analysed, only 5 contained food; a total of 41 prey items was found, corresponding to 19 categories of prey items (Table 2). Calanoid copepods were the most abundant (15 individuals) and frequently captured (in 4 stomachs) item, and Calocaris macandreae was the heaviest prey $(\% W=53.01)$. Other relatively abundant prey were mysids (4 Bore- omysis arctica), gammarid amphipods (3 Lyssianasidae and 1 Orchomene humilis) and polychaetes (2 Flabelligeridae). The mean number of prey per stomach was very high $\left(N_{p}=8.2\right.$ : Table 3$)$.

\section{DISCUSSION}

The macrourids analysed had a relatively broad diet $\left(H^{\prime}=3.05\right.$ to 4.90$)$, the most euryphagous being Coryphaenoides guentheri and the least being Trachyrhynchus trachyrhynchus.

Chalinura mediterranea, Coelorhynchus labiatus and Trachyrhynchus trachyrhynchus in the Mediterranean have a benthopelagic diet, whilst Coryphaenoides guentheri has a benthic diet. In this study, the diet of Coelorhynchus labiatus (which, according to Cohen et al. 1990, replaces Coelorhynchus occa in the eastern Atlantic) has been analysed for the first time in the Mediterranean. Although the number of specimens was not very large, it is clear that C. labiatus feed on benthopelagic prey, with a slight preference for bathybenthic prey (polychaetes, gammaridean amphipods). Chalinura mediterranea and T. trachyrhynchus, also benthopelagic, have a slight preference for bathypelagic prey (calanoid copepods and mysids in both species and natantian decapods in C. mediterranea) over benthic prey (amphipods, polychaetes). In 1 specimen of $C$. mediterranea, Geistdoerfer (1978) in the Mediterranean also observed that it consumes copepods, isopods and decapods. On the other hand, Coryphaenoides guentheri in the NW Mediterranean is primarily a benthic feeder, consuming mainly gammaridean amphipods and cumaceans, supplemented by polychaetes and a wide variety of other organisms such as isopods, copepods and mysids. The only specimen analysed in the Mediterranean contained an isopod and a mysid (Geistdoerfer 1978).

The different diets of 1425 to $1800 \mathrm{~m}$ and 1800 to $2250 \mathrm{~m}$ specimens of Chalinura mediterranea and of summer and autumn specimens of Coryphaenoides guentheri may be the consequence of a change in available resources. This is the case for Boreomysis arctica (Cartes \& Sorbe 1995), Acanthephira eximia (Cartes \& Sardà 1992) and Platysympus typicus (Cartes \& Sorbe 1997), which are most abundant at great depths (1800 to $2250 \mathrm{~m}$ ), and for Pontophilus norvegicus, which is most abundant at 1000 to $1700 \mathrm{~m}$ (Cartes \& Sardà 1992), coinciding with that observed in the diet of Chalinura mediterranea. Our preliminary observations of the diet of autumn specimens of Coryphaenoides guentheri are not conclusive because of the limited number of specimens that could be analysed. Nevertheless, our data suggest a difference 
in the prey consumed in autumn and summer (Schoener index $=0.42$ to 0.47 ), with polychaetes, which are secondary prey in summer, becoming the principal prey in autumn and the mysids undergoing an important recruitment in late autumn (Cartes 1998). This seasonal fluctuation in the feeding pattern of Coryphaenoides guentheri offers a plausible hypothesis to explain growth seasonality, which is well documented by the periodicity of otolith ring formation (MoralesNin 1990, Massutí et al. 1995) in fish species of the deep Mediterranean, where temperature and salinity cannot be causative factors because they are fairly constant below 150 to $200 \mathrm{~m}$. The bathymetric differences in the diet of summer specimens of Coryphaenoides guentheri and in the diet of Chalinura mediterranea are also marked by greater vacuity, a greater consumption of prey, and a greater diversity at 1800 to $2250 \mathrm{~m}$ than at 1425 to $1800 \mathrm{~m}$. The scarcity of resources, which decrease steadily below 1200 to $1400 \mathrm{~m}$ (Cartes \& Sorbe 1993, Cartes 1998), may force these species to diversify their diet at 1800 to $2250 \mathrm{~m}$, extending it to include other prey such as ostracods, cumaceans or decapod macrurans. Decreasing specialization with increasing depth, as observed in the macrourids analysed, enables deep-sea predators to be more adaptable (Dayton \& Hessler 1972).

Trachyrhynchus trachyrhynchus, which occurs in this region at depths of 200 to $1589 \mathrm{~m}$ (Macpherson 1979, Stefanescu et al. 1992a, Massutí et al. 1995), also seems to exhibit bathymetric changes in its diet. At 200 to $800 \mathrm{~m}$ depth $T$. trachyrhynchus is stenophagous, tending to feed on infauna (Macpherson 1979); however, below a depth of $1000 \mathrm{~m}$, despite the few specimens examined, a benthopelagic diet emerged with a slight preference for bathypelagic (copepods and mysids) over benthic prey.

The differences in the feeding habits of the Mediterranean and Atlantic fish populations, which have already been observed in other species in the same zone, such as Centroscymnus coelolepis (Carrassón et al. 1992) and Alepocephalus rostratus (Carrassón \& Matallanas 1998), were also observed in the 4 macrourids analysed in the present study. These differences are as apparent in the prey-species consumed as in the type of prey-species or in the feeding intensity and alimentary diversity. Thus, Atlantic Chalinura mediterranea, which also has a benthopelagic diet (Mauchline \& Gordon 1984a), consumes copepods with greater frequency ( $\% N$ between 45.4 and 61.2 ) than Mediterranean individuals (maximum \% $N 31.6$ at 1425 to $1800 \mathrm{~m}$ depth). The co-dominance of copepods, amphipods and mysids on a weight basis observed in the diet of Atlantic specimens, is not observed in Mediterranean specimens, for which amphipods constitute the secondary prey. However, certain prey (euphausiids, cephalopods and chaetognaths) occur in Atlantic specimens (Marshall \& Merrett 1977, Mauchline \& Gordon 1984a, Gordon \& Duncan 1987) but not in Mediterranean specimens, and vice versa, e.g. foraminiferans, ostracods and tanaidaceans, are found in Mediterranean but not in Atlantic specimens.

In the case of Coryphaenoides guentheri, differences between the Mediterranean and Atlantic populations, are clearer, since in Atlantic waters it is a benthopelagic feeder (Mauchline \& Gordon 1984a, Gordon \& Duncan 1987), including epibenthic components in its diet and also sediment (Mauchline \& Gordon 1984b), whereas in Mediterranean waters it is primarily a benthic feeder. The copepods and amphipods that dominate the diet of specimens from the 1000 to $2500 \mathrm{~m}$ depth range (Mauchline \& Gordon 1984a) and from the 2200 to $2900 \mathrm{~m}$ depth range (Gordon \& Duncan 1987) in the Atlantic are totally accidental in the diet of specimens in the Mediterranean. On the other hand, in spite of a slight increase in the size of the prey with increasing predator size, in the Mediterranean specimens of Coryphaenoides guentheri the bathymetric dietary differences found were clearer than ontogenic differences (Fig. 2). Thus, a relative increase in the importance of cumaceans occurred in specimens at 1800 to $2250 \mathrm{~m}$ (D2) compared to specimens at 1425 to $1800 \mathrm{~m}$ (D1). The overlap in the Schoener index among the prey-species consumed indicates that these differences are greater among the autumn D1 and D2 individuals than among D1 and D2 individuals at summer. In Atlantic specimens of Coryphaenoides guentheri, Mauchline \& Gordon (1984a) found important ontogenic differences in small-sized individuals, which live only between 1000 and $1250 \mathrm{~m}$, compared with the remaining size-groups. The lack of differences between small and large Mediterranean species (Fig. 2) could indicate that the Atlantic results are related to the bigger-deeper trend displayed by Coryphaenoides guentheri (as by Coelorhynchus labiatus and Chalinura mediterranea) in North Atlantic waters (Mauchline \& Gordon 1984a, Gordon \& Duncan 1987, Merrett et al. 1991), which does not occur in Mediterranean specimens. Thus, in addition to (as indicated by Mauchline \& Gordon 1984a) being a direct result of the smaller size of the fish and their selection of smaller sized prey organisms, these ontogenic differences would be the result of bathymetric differences in the prey availability in relation to the predator. None of the exclusively lower-slope species in the Western Mediterranean (among them, Coryphaenoides guentheri and Chalinura mediterranea) showed any significant size-depth variation or trend (Stefanescu et al. 1992b), and in Mediterranean waters the bathymetric differences in diet of these 2 macrourids may mainly reflect a change in prey availability. 


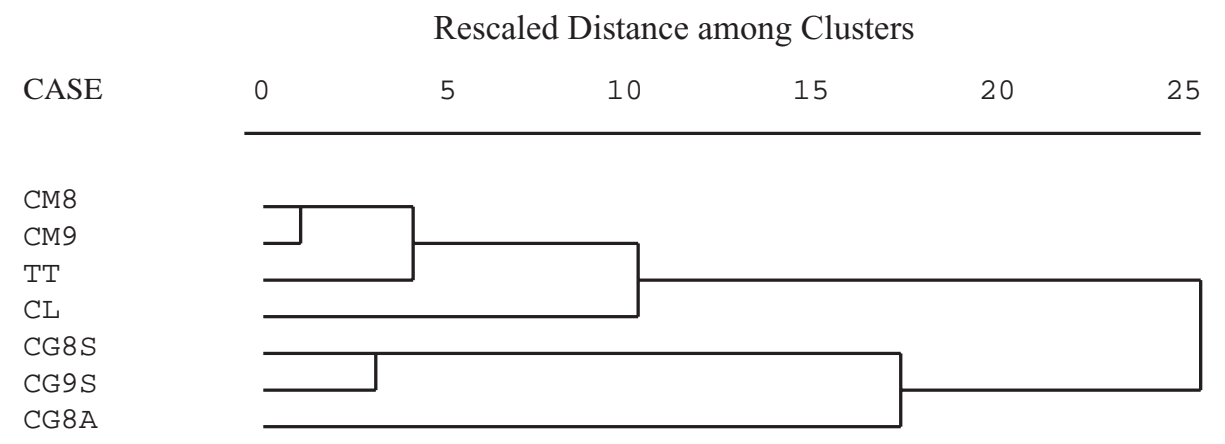

Fig. 4. Dendrogram of dissimilarity between diets of different groups (bathymetric, seasonal and ontogenic) of macrourids analysed. CM8: Chalinura mediterranea from 1425 to $1800 \mathrm{~m}$ depth; CM9: Chalinura mediterranea from 1800 to $2250 \mathrm{~m}$ depth; TT: Trachyrhynchus trachyrhynchus; CL: Coelorhynchus labiatus; CG8S: summer individuals of Coryphaenoides guentheri from 1425 to $1800 \mathrm{~m}$ depth; CG9S: summer individuals of Coryphaenoides guentheri from 1800 to $2250 \mathrm{~m}$ depth; CG8A: autumn individuals of Coryphaenoides guentheri from 1425 to $1800 \mathrm{~m}$ depth

Coelorhynchus labiatus in the Atlantic consumes copepods, decapods, polychaetes, amphipods, isopods and fishes (Marshall \& Iwamoto 1973, Marshall \& Merrett 1977, du Buit 1978), preferring bathypelagic prey such as copepods (Mauchline \& Gordon 1984a), with bathybenthic prey being only occasional (polychaetes: $\% N=6 \%$; amphipods: $\% N=8 \%$ ). However, in the Mediterranean populations, bathybenthic prey are the main prey.

The feeding habits of Trachyrhynchus trachyrhynchus in the Atlantic vary regionally and, as with the Mediterranean population, in the SE Atlantic large individuals also feed mainly on bathypelagic prey, with small individuals feeding more on bathybenthic organisms (Macpherson 1983), whilst those in the NE Atlantic have a mixed diet, pelagic and benthic (Marshall \& Merrett 1977, McLellan 1977, Geistdoerfer 1978, Hureau et al. 1979, Merrett \& Marshal 1981).

The significantly smaller size of Mediterranean populations of Chalinura mediterranea and Coryphaenoides guentheri compared to Atlantic populations (Geistdoerfer 1986) (340 and $730 \mathrm{~mm}$ TL for Chalinura mediterranea, and 220 and $480 \mathrm{~mm}$ TL for Coryphaenoides guentheri) and of Coelorhynchus labiatus (244 mm TL in Mediterranean specimens, $380 \mathrm{~mm}$ TL in Atlantic specimens: Mauchline \& Gordon 1984a) provides further proof of the adaptation of the Mediterranean populations to a poorer environment. The Mediterranean is an environment which, below $1000 \mathrm{~m}$ depth, becomes progressively more trophically restrictive; increasing oligotrophy with increasing depth is reflected by an important drop in macrofaunal and megafaunal biomass between 1000 and $2250 \mathrm{~m}$ (Stefanescu et al. 1992b, Sardà \& Cartes 1993, Cartes 1998).

Macpherson (1979) showed that rates of competitive exclusion were low among 4 species of macrourids on the upper-middle slope ( 200 to $800 \mathrm{~m}$ ) of the Mediterranean, and stated that macrourids, in general, have narrow diets, exhibiting some specialisation. The present study makes it clear that in the middle-lower slope (below $1000 \mathrm{~m}$ ) this strategy changes with the macrourids becoming euryphagic predators, with a wide variety of prey.

Dendogram of dissimilarity between diets of all macrourids analysed below $1000 \mathrm{~m}$ depth are shown in Fig. 4. The apparent similarity between the diets of Chalinura mediterranea and Trachyrhynchus trachyrhynchus could explain the bathymetric segregation of their respective niches. Their habitat widths do not overlap in this depth zone (Stefanescu et al. 1992a). On the other hand, Coryphaenoides guentheri and Chalinura mediterranea, which coexist from 1308 to $2250 \mathrm{~m}$, showing an almost total overlap of their respective space niches (Stefanescu et al. 1992a), have marked differences in their diets, one feeding on benthic prey and the other preferentially on bathypelagic prey. Finally, Coelorhynchus labiatus has a dietary overlap intermediate to those of the other 3 species of macrourids, as visible from Fig. 4, which shows that its diet is different from that of the benthopelagic feeders associated with it. Their habitat width is 1200 to $1700 \mathrm{~m}$ in the Western Mediterranean (Stefanescu et al. 1992a), i.e. in the depth zone where the dominant medium-sized macrourid species $T$. trachyrhynchus is replaced by smaller species (Chalinura mediterranea and Coryphaenoides guentheri). Similar to macrourids of the NE Atlantic (Mauchline \& Gordon 1984a), all Mediterranean macrourids are generalist feeders, and ecological separation is mantained by a combination of differential depth distribution and feeding habits.

A detailed examination of resources among macrourids has been described in this paper; however, this is of limited value unless considered within the context of the fish associations of the region as a whole. This will be attempted for the Catalan Sea (Western Mediterranean) in a later paper. 
Acknowledgements. Thanks are due to all the members of the BATIMAR research program for their collaboration, especially to Drs J. Rucabado and D. Lloris. We are grateful to Dr J. E. Cartes for his collaboration in identifying several species. The BATIMAR project was financed by CSIC and CAICYT (PAC 86-008/ID 821). The RETRO project was also financed by CSIC and CAICYT (MAR90-757).

\section{LITERATURE CITED}

Carrassón M, Matallanas J (1994) Morphometric characteristics of the alimentary tract of deep-sea Mediterranean teleosts in relation to their feeding habits. Mar Biol 118: 319-322

Carrassón M, Matallanas J (1998) Feeding habits of Alepocephalus rostratus (Pisces: Alepocephalidae) in the western Mediterranean sea. J Mar Biol Assoc UK 78: 1295-1306

Carrassón M, Matallanas J (2001) Feeding ecology of the Mediterranean spiderfish Bathypterois mediterraneus (Pisces: Chlorophtalmidae) on the western Mediterranean slope. Fish Bull (Wash DC) 99:266-274

Carrassón M, Stefanescu C, Cartes JE (1992) Diets and bathymetric distributions of two bathyal sharks of the Catalan deep sea (western Mediterranean). Mar Ecol Prog Ser 82: 21-30

Carrassón M, Matallanas J, Casadevall M (1997) Feeding strategies of deep-water morids on the western Mediterranean slope. Deep-Sea Res 44:1685-1699

Cartes JE (1998) Dynamics of the bathyal benthic boundary layer in the northwestern Mediterranean: depth and temporal variations in macrofaunal-megafaunal communities and their possible connections within deep-sea trophic webs. Prog Oceanogr 41:111-139

Cartes JE, Sardà F (1992) Abundance and diversity of decapod crustaceans in the deep-Catalan sea (western Mediterranean). J Nat Hist 26:1305-1323

Cartes JE, Sardà F (1993) Zonation of deep-sea decapod fauna in the Catalan Sea (Western Mediterranean). Mar Ecol Prog Ser 94:27-34

Cartes JE, Sorbe JC (1993) Les communautés suprabenthiques bathyales de la Mer Catalane (Mediterranée occidentale): données préliminaires sur la repartition bathymétrique et lábondance des crustacés péracarides. Crustaceana 64(2):155-171

Cartes JE, Sorbe JC (1995) Deep-water mysids of the Catalan sea: species composition, bathymetric and near-bottom distribution. J Mar Biol Assoc UK 75:187-197

Cartes JE, Sorbe JC (1997) Bathyal cumaceans of the Catalan Sea (north-western Mediterranean): faunistic composition, diversity and near-bottom distribution along the slope (between 389 and $1859 \mathrm{~m}$ ). J Nat Hist 31:1041-1054

Cohen DM, Inada T, Iwamoto T, Scialabba N (1990) Gadiform fishes of the world (order Gadiformes). An annotated and illustrated catalogue of cods, hakes, grenadiers and other gadiform fishes known to date. FAO Fish Synop 10:1-442

Dayton PK, Hessler RR (1972) Role of biological disturbance in maintaining diversity in the deep sea. Deep-Sea Res 19: 199-208

du Buit MH (1978) Alimentation de quelques poissons téléostéens de profondeur dans la zone du seuil de Wyville Thomson. Oceanol Acta 1:129-134

Geistdoerfer P (1978) Écologie alimentaire des Macrouridae. Rev Trav Inst Pêches Marit 42:177-260

Geistdoerfer P (1978-1979) Connaissances nouvelles sur la biologie de la famille des Macrouridae (Téléostéens Gadiformes). Vie Milieu 28-29:323-351

Geistdoerfer P (1986) Macrouridae. In: Whitehead PJP, Bauchot ML, Hureau JC, Nielsen J, Tortonese E (eds) Fishes of the North-eastern Atlantic and the Mediterranean, Vol 1. UNESCO, Bungay

Gordon JDM, Duncan JAR (1987) Deep-sea bottom living fishes at two repeat stations at 2200 and $2900 \mathrm{~m}$ in the Rockall Trough, northeastern Atlantic Ocean. Mar Biol 96: 309-325

Gordon JDM, Mauchline J (1990) Depth-related trends in diet of a deep-sea bottom-living fish assemblage of the Rockall Trough. In: Barnes M, Gibson RN (eds) Trophic relationships in the marine environment. Proceedings of the 24th European Marine Biological Symposium. Aberdeen University Press, Aberdeen, p 439-452

Haedrich RL, Merrett NR (1988) Summary atlas of deep-living demersal fishes in the North Atlantic Basin. J Nat Hist 22: $1325-1362$

Hureau JC (1970) Biologie comparée de quelques poissons antarctiques (Nototheniidae). Bull Inst Océanogr (Monaco) 68(1391):1-250

Hureau JC, Geistdoerfer P, Rannou M (1979) The ecology of deep-sea benthic fishes. Sarsia 64:103-107

Macpherson E (1979) Ecological overlap between macrourids in the Western Mediterranean Sea. Mar Biol 53:149-159

Macpherson E (1981) Resource partitioning in a Mediterranean demersal fish community. Mar Ecol Prog Ser 4: 183-193

Macpherson E (1983) Ecología trófica de peces en las costas de Namibia. I. Hábitos alimentarios. Result Exped Cient 11:81-137

Marshall NB (1965) Systematical and biological studies of the Macrourid fishes (Anacanthini-Teleostii). Deep-Sea Res 12:299-322

Marshall NB, Iwamoto T (1973) Family Macrouridae. Mem Sears Found Mar Res 6:496-537

Marshall NB, Merrett NR (1977) The existence of a benthopelagic fauna in the deep-sea. Deep-Sea Res 24 (Suppl): 483-497

Massutí E, Morales-Nin B, Stefanescu C (1995) Distribution and biology of five grenadier fish (Pisces: Macrouridae) from the upper and middle slope of the northwestern Mediterranean. Deep-Sea Res Part I Oceanogr Res Pap 42: $307-330$

Mauchline J, Gordon JDM (1984a) Diets and bathymetric distributions of the macrourid fish of the Rockall Trough, northeastern Atlantic Ocean. Mar Biol 81:107-121

Mauchline J, Gordon JDM (1984b) Occurrence of stones, sediment and fish scales in stomach contents of demersal fish of the Rockal Trough. J Fish Biol 24:357-362

Mauchline J, Gordon JDM (1985) Trophic diversity in deepsea fish. J Fish Biol 26:527-535

Mauchline J, Gordon JDM (1986) Foraging strategies of deep-sea fish. Mar Ecol Prog Ser 27:227-238

McLellan T (1977) Feeding strategies of the macrourids. Deep-Sea Res 24:1019-1036

Merrett NR (1987) A zone of faunal change in assemblages of abyssal demersal fish in the eastern north Atlantic: a response to seasonality in production? Biol Oceanogr 5: $137-151$

Merrett NR, Marshall NB (1981) Observations on the ecology of deep-sea bottom-living fishes collected off northwest Africa $\left(08^{\circ}-27^{\circ} \mathrm{N}\right)$. Prog Oceanogr 9:185-244

Merrett NR, Haedrich RL, Gordon JDM, Stehmann M (1991) Deep demersal fish assemblage structure in the Porcupine Seabight (eastern north Atlantic): results of single warp 
trawling at lower slope to abyssal soundings. J Mar Biol Assoc UK 71:359-373

Morales-Nin B (1990) A first attempt at determining growth patterns of some Mediterranean deep-sea fishes. Sci Mar 54:241-248

Pinkas L, Oliphant MS, Iverson ILK (1971) Food habits of albacore, bluefin tuna and bonito in California waters. Calif Dep Fish Game Fish Bull 152:1-105

Rosecchi E, Nouaze Y (1987) Comparaison de cinq indices alimentaires utilisés dans l'analyse des contenus stomacaux. Rev Trav Inst Pêches Marit 49:111-123

Sardà F, Cartes JE (1993) Relationship between size and depth in decapod crustacean populations on the deep slope in the western Mediterranean. Deep-Sea Res Part I Oceanogr Res Pap 40:2389-2400

Sardà F, Cartes JE, Company JB (1994) Spatio-temporal variations in megabenthos abundance in three different habitats of the Catalan deep-sea (western Mediterranean). Mar Biol 120:211-219

Editorial responsibility: Otto Kinne (Editor),

Oldendorf/Luhe, Germany
Schoener TW (1974) Resource partitioning in ecological communities. Science 185:27-39

Stefanescu C, Loris D, Rucabado J (1992a) Deep-living demersal fishes in the Catalan Sea (western Mediterranean) below a depth of $1000 \mathrm{~m}$. J Nat Hist 26:197-213

Stefanescu C, Rucabado J, Lloris D (1992b) Depth-size trends in western Mediterranean demersal deep-sea fishes. Mar Ecol Prog Ser 81(3):205-213

Stefanescu C, Lloris D, Rucabado J (1993) Deep-sea fish assemblages in the Catalan Sea (western Mediterranean) below a depth of $1000 \mathrm{~m}$. Deep-Sea Res 40: 695-707

Stefanescu C, Morales-Nin B, Massutí E (1994) Fish assemblages on the slope in the Catalan Sea (western Mediterranean): influence of a submarine canyon. J Mar Biol Assoc UK 74:499-512

Yasuda F (1960) The types of food habits of fishes assured by stomach contents examination. Bull Jpn Soc Sci Fish 26: 653-662

Submitted: May 4, 2001; Accepted: December 11, 2001

Proofs received from author(s): April 29, 2002 